\title{
Bacteriocin production: a relatively unharnessed probiotic
}

\section{trait? [version 1; peer review: 2 approved]}

\author{
James W. Hegarty ${ }^{1,2}$, Caitriona M. Guinane ${ }^{1}$, R. Paul Ross ${ }^{1,3}$, Colin Hill2,3, \\ Paul D. Cotter ${ }^{1,3}$
}

${ }^{1}$ Teagasc Food Research Centre, Moorepark, Fermoy, Co. Cork, Ireland

${ }^{2}$ Department of Microbiology, University College Cork, Cork, Ireland

${ }^{3}$ APC Microbiome Institute, University College Cork, Cork, Ireland

V1 First published: 27 Oct 2016, 5(F1000 Faculty Rev):2587

https://doi.org/10.12688/f1000research.9615.1

Latest published: 27 Oct 2016, 5(F1000 Faculty Rev):2587

https://doi.org/10.12688/f1000research.9615.1

\section{Abstract}

Probiotics are "live microorganisms which, when consumed in adequate amounts, confer a health benefit to the host". A number of attributes are highly sought after among these microorganisms, including immunomodulation, epithelial barrier maintenance, competitive exclusion, production of short-chain fatty acids, and bile salt metabolism. Bacteriocin production is also generally regarded as a probiotic trait, but it can be argued that, in contrast to other traits, it is often considered a feature that is desirable, rather than a key probiotic trait. As such, the true potential of these antimicrobials has yet to be realised.

\section{Keywords}

probiotic , bacteriocin , microbiota , gut health

\section{Open Peer Review \\ Approval Status \\ 1 \\ 2 \\ version 1 \\ 27 Oct 2016 \\ Faculty Reviews are review articles written by the prestigious Members of Faculty Opinions. The articles are commissioned and peer reviewed before publication to ensure that the final, published version is comprehensive and accessible. The reviewers who approved the final version are listed with their names and affiliations.}

\section{Michael Chikindas, Rutgers State University, New Brunswick, USA \\ New Jersey Institute for Food, Nutrition and Health, New Brunswick, USA \\ 2. Antonio Galvez, Universidad de Jaén, Jaén, Spain}

Any comments on the article can be found at the end of the article. 
Corresponding author: Paul D. Cotter (paul.cotter@teagasc.ie)

Competing interests: The authors declare that they have no competing interests.

Grant information: This work was funded by a Science Foundation Ireland award "Obesibiotics" (11/P1/1137) to PDC.

The funders had no role in study design, data collection and analysis, decision to publish, or preparation of the manuscript.

Copyright: @ 2016 Hegarty JW et al. This is an open access article distributed under the terms of the Creative Commons Attribution License, which permits unrestricted use, distribution, and reproduction in any medium, provided the original work is properly cited.

How to cite this article: Hegarty JW, Guinane CM, Ross RP et al. Bacteriocin production: a relatively unharnessed probiotic trait?

[version 1; peer review: 2 approved] F1000Research 2016, 5(F1000 Faculty Rev):2587 https://doi.org/10.12688/f1000research.9615.1

First published: 27 Oct 2016, 5(F1000 Faculty Rev):2587 https://doi.org/10.12688/f1000research.9615.1 


\section{What are bacteriocins?}

Bacteriocins are small, heat-stable, ribosomally synthesised antimicrobial peptides produced by bacteria that are active against other bacteria and to which the producer is immune ${ }^{1}$. These peptides exhibit considerable diversity with respect to their size, structure, mechanism of action, inhibitory spectrum, immunity mechanisms, and target cell receptors ${ }^{2}$. Indeed, for example, many bacteriocins have a narrow spectrum of activity, displaying antimicrobial activity against strains that are closely related to the producer, whereas others display antimicrobial activity across a broad variety of different genera ${ }^{1}$. The regulation of bacteriocin production can be complex, in some instances being influenced by environmental conditions such as $\mathrm{pH}$, temperature, and growth medium $^{3-5}$.

Despite the diversity among bacteriocins, they can generally be classified into one of two groups on the basis of whether they undergo post-translational modifications ${ }^{1}$. Class I (modified) bacteriocins have been further subdivided into the following subgroups: lantibiotics, linaridins, linear azol(in)e-containing peptides, cyanobactins, thiopeptides, lasso peptides, sactibiotics, glycocins, and modified microcins ${ }^{6}$. Class II (unmodified) bacteriocins consist of five subgroups: four correspond to the unmodified lactic acid bacteria (LAB) bacteriocins and one corresponds to the unmodified microcins and includes class IIa (pediocin-like), IIb (two-peptide bacteriocins), IIc (circular bacteriocins), IId (linear, non-pediocin-like bacteriocins), and IIe (microcin E492-like bacteriocins).

Antimicrobial/bacteriocin production may contribute to probiotic functionality through three different mechanisms ${ }^{7}$ : firstly, as colonising peptides, bacteriocins aid the survival of the producing strain in the gut environment ${ }^{8}$; secondly, bacteriocins function through direct inhibition of the growth of pathogens ${ }^{9}$; and, finally, bacteriocins may serve as signalling peptides/quorum-sensing molecules in the intestinal environment ${ }^{10}$. However, although bacteriocin production is generally regarded as a probiotic trait, it can be argued that, in contrast to other traits, it is often considered a feature that is desirable, rather than a key probiotic trait. As such, the true potential of these peptides for gut health, and indeed other applications ${ }^{11}$, has yet to be realised.

\section{Bacteriocin-producing probiotic strains}

Probiotics are "live microorganisms which, when consumed in adequate amounts, confer a health benefit to the host"12. The majority of probiotic species in commercial use today are representatives of the genera Lactobacillus or Bifidobacterium. However, despite the health-promoting attributes associated with Bifidobacterium spp. and their potential ability to produce these antimicrobials, there is limited information available regarding functional bacteriocin production by bifidobacteria ${ }^{13}$. This raises the following question: is bacteriocin production a rare trait among bifidobacteria or are bacteriocin-producing bifodobacteria being overlooked or not being effectively harnessed? Interestingly, while examining the diversity and distribution of bacteriocins from different body sites, Zheng et al. reported the absence of bacteriocins produced by Bifidobacterium spp. in the gut, despite bifidobacteria accounting for up to $10 \%$ of the microbiome ${ }^{14}$. Walsh et al. identified just two novel putative bacteriocin gene clusters, belonging to the lantibiotic class, from two Bifidobacterium spp. during a screen of the gastrointestinal (GI) tract subset of the Human Microbiome Project reference genome database ${ }^{15}$, again emphasising the rarity of production among this genus. Other probiotics include specific strains of Streptococcus spp., Lactococcus spp., and Enterococcus spp. as well as the Escherichia coli strain Nissle 1917 and yeasts such as Saccharomyces boulardii ${ }^{16,17}$. As lactococci are not typically regarded as gutassociated microorganisms and the use of enterococci as probiotics is controversial, for the purposes of this review we have focused on reviewing what is known about bacteriocin production from among probiotic lactobacilli and streptococci of human origin and discussing the extent to which this trait is valued when commercialising associated strains (Figure 1).

\section{Probiotic lactobacilli}

The mechanism by which bacteriocin production contributes to probiotic functionality among species of Lactobacillus has been the focus of a number of studies. van Hemert et al. reported that genes required for plantaricin production and transport contributed to the immunomodulatory effects of Lactobacillus plantarum WCFS1 on peripherial blood mononuclear cells ${ }^{10}$. Using the same strain of L. plantarum, Meijerink et al. established that six of the eight genes that modulate the dendritic cell cytokine response were involved in bacteriocin production or secretion ${ }^{18}$. The beneficial impact of using L. johnsonii La1 to control Helicobacter pylori colonisation was also previously examined ${ }^{19}$.

A number of strains of Lactobacillus salivarius which possess probiotic traits have been identified, and the genus is also associated with the production of a number of class II ( $a, b$, and d) bacteriocins ${ }^{20-24}$. Despite the fact that bacteriocins produced by potential probiotic strains have significant promise as alternative treatments to target clinically relevant pathogens, the degree to which they are expressed under the harsh conditions within the GI tract has not been studied in great detail. For the same reason, strategies have not been developed to ensure that bacteriocin production is triggered within this environment. It has only been established that certain bacteriocins produced by $L$. salivarius strains can indeed be produced within many of the stressful conditions encountered in the gut ${ }^{3,25}$. L. salivarius UCC118 (NCIMB 40829 LSUCC118) is a very well-characterised strain that has been studied with a view to potential probiotic applications and that notably produces the class II, two-peptide bacteriocin Abp $118^{26}$. Abp118 displays a relatively broad spectrum of antimicrobial activity against a number of food-borne and medically significant pathogens ${ }^{27}$. This probiotic strain was the focus of particular attention when it was employed in an important 'proof-of-concept' study, which proved that bacteriocin production is indeed a probiotic trait by virtue of its ability to protect mice against Listeria monocytogenes infection'. The strain and a non-bacteriocinproducing equivalent were also used by Murphy et al. to test their relative abilities to mitigate the metabolic abnormalities associated with obesity in a diet-induced obesity (DIO) mouse model and modulate the gut microbiota as a potential driver of these abnormalities $^{28}$. Although reductions in weight gain were evident among animals that received the bacteriocin-producing strain, these effects were transient. It was notable that the composition of the murine gut microbiota differed depending on which strain they were fed, indicating in situ functionality ${ }^{28}$. As the ability to adhere to intestinal epithelium can play a role in probiotic 


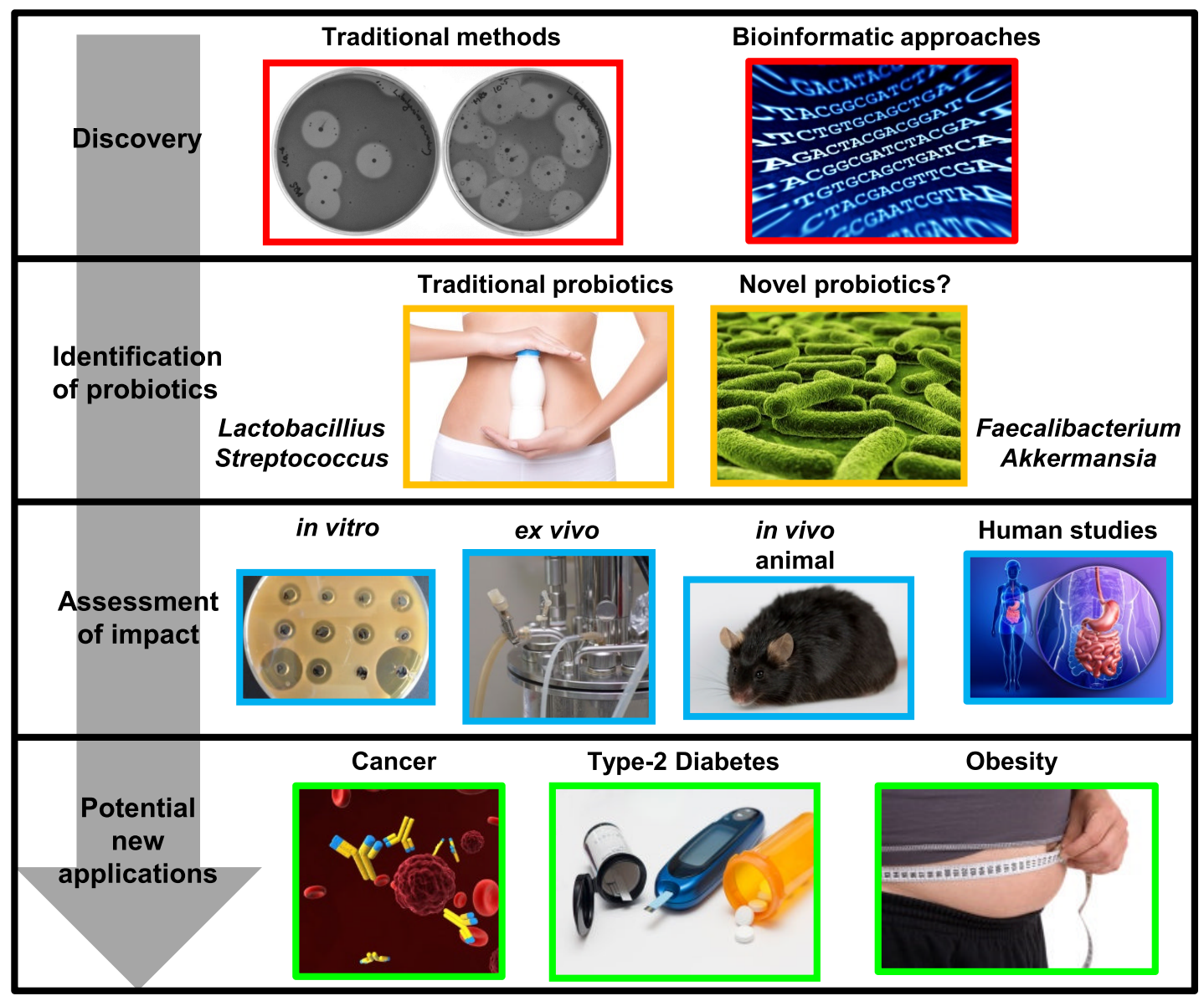

Figure 1. Bacteriocins, from discovery to potential probiotic application. Strategies to identify new bacteriocins include culture-based methods and newer bioinformatics-based approaches. These can lead to the identification of bacteriocin-producing strains from traditionally utilised, or novel, probiotic species. The impact of a bacteriocin-producing strain on health can be assessed using in vitro, ex vivo, and in vivo methods and, depending on the outcome, has the potential to be applied to prevent or treat various disease states.

functionality, this strain has also been examined to assess the influence of adhesion to intestinal epithelial cells on gene expression. Notably, bacteriocin gene expression was induced upon adhesion to epithelial cells, possibly through a mechanism whereby the presence of an induction peptide at a high enough local concentration triggers bacteriocin production. The phenomenon was observed for the UCC118 wild-type strain but not an srtA mutant, as disruption of the sortase gene $s r t A$ results in significantly lower levels of adhesion ${ }^{29}$, following exposure to Caco-2 cells ${ }^{30}$. It is notable that, despite UCC118 being perhaps the probiotic strain in which the benefits of bacteriocin production are clearest, the strain has yet to be brought to market. Another L. salivarius-produced bacteriocin that has been the focus of investigation is bactofencin A, a class IId bacteriocin ${ }^{24}$. This bacteriocin is unusual in that it does not share significant homology with previously characterised bacteriocins but instead is more similar to a group of eukaryotic antimicrobial peptides ${ }^{24}$.
Bactofencin A has a relatively broad spectrum of activity, inhibiting two clinically significant pathogens: Staphylococcus aureus and L. monocytogenes ${ }^{24}$. The impact of the bactofencin A-producing strain on intestinal populations and microbial diversity in a simulated model of the distal colon has been examined ${ }^{25}$ and was found to alter the proportions of a number of important gut genera, including Fusobacterium, Bacteroides, and Bifidobacterium, resulting in a positive, albeit subtle, effect on gut populations ${ }^{25}$.

Despite the research described above, bacteriocin production among commercial probiotic lactobacilli has, in general, not been studied in great detail, and the information available regarding which commercial probiotics produce bacteriocins and which bacteriocins are produced most frequently is limited. Lactobacillus acidophilus probiotics, several of which are employed for use in commercial products $^{31,32}$, are somewhat exceptional in this regard in that two such strains, NCFM and LA-5, are known to produce the 
bacteriocin lactacin $\mathrm{B}^{33,34}$. This bacteriocin has a narrow spectrum of activity, capable of inhibiting other lactobacilli and Enterococcus faecalis $^{35}$. Notably, with respect to this commentary, the contribution of lactacin B, if any, to probiotic functionality has not been determined.

\section{Streptococcus salivarius}

Streptococcus salivarius is a well-characterised human commensal of the oral cavity ${ }^{36}$ and has been found to colonise within just a few hours of birth ${ }^{37}$. It is also a common inhabitant of the gut, particularly the stomach and jejunum. Some strains of $S$. salivarius have gained attention because of their role as safe and effective probiotics, and have been employed to promote a healthy oral microbiota $^{38,39}$. As reviewed by Wescombe et al., strain K12 is the model $S$. salivarius probiotic and is available in commercial preparations (BLIS K12; BLIS Technologies, Otago, New Zealand). K12 was initially selected because of its ability to inhibit the pathogen Streptococcus pyogenes, but now several other health-promoting effects have been noted ${ }^{40}$. This includes the ability to inhibit group B streptococci $(\mathrm{GBS})^{41}$, including isolates suspected of causing disease in newborns and colonising isolates from the vaginal tract of pregnant women. Some of these activities were dependent, or partially dependent, on the presence of a megaplasmid that encodes the salivaricin A2 and salivaricin B bacteriocins ${ }^{41}$.

Other strains of $S$. salivarius examined for their probiotic application include M18, which contains a megaplasmid encoding a number of bacteriocins ${ }^{42}$. To evaluate its probiotic potential, the impact of this strain to prevent or reduce the risk of dental caries and influence dental health was examined in a randomised, double-blind, placebo-controlled trial ${ }^{43}$. The persistence of this strain in saliva was also investigated and revealed to be dose dependent ${ }^{44}$. This study demonstrated in vitro transfer of the bacteriocin-encoding megaplasmids between two strains of S. salivarius. This may allow the enhancement of probiotic strains by transferring the megaplasmid from those that persist poorly but demonstrate strong bacteriocin production to indigenous S. salivarius that persist strongly but demonstrate poor bacteriocin production ${ }^{44}$. Additionally, the identification of novel bacteriocins, including salivaricin $9^{45}$ and the recently identified salivaricin $\mathrm{E}^{46}$, from this species continues to enhance the probiotic potential of S. salivarius.

\section{Novel health targets for bacteriocins}

The ability of bacteriocins to modulate the gut microbiota by targeting undesirable components without having a negative impact on the beneficial populations is an attractive trait. The role by which a bacteriocin could regulate niche competition among enterococci or between enterococci and the intestinal microbiota was examined by Kommineni et al. ${ }^{47}$. Here, it was demonstrated that E. faecalis containing the conjugative pPD1 plasmid, which expresses bacteriocin 21 , both replaced indigenous enterococci and outcompeted E. faecalis, which lacked the plasmid, while the transfer of this plasmid to other E. faecalis strains enhanced their survival in the intestine. Finally, vancomycin-resistant enterococci were cleared following subsequent colonisation with E. faecalis harbouring a conjugation-defective pPD1 mutant ${ }^{47}$. These results do indeed demonstrate that bacteriocin production by commensal bacteria contributes to niche competition and an alternative therapeutic approach to eliminating intestinal colonisation by multidrug-resistant bacteria may be provided by bacteriocins delivered by commensals ${ }^{47}$.

Janek et al. observed a high frequency of bacteriocin production among nasal Staphylococcus strains with highly variable antimicrobial activity against other nasal members, suggesting a need to inhibit different competitors ${ }^{48}$. The diverse activity spectra of bacteriocins within the nose may facilitate the ability of a bacterial species to dominate the resident populations, suggesting the development of probiotics that could promote a desirable microbiota composition and eliminate pathogens such as S. aureus $^{48}$.

The majority of studies to date, focus on bacteriocin-producing probiotics that can inhibit well-established gut pathogens. Nextgeneration sequencing technologies continue to provide a more thorough understanding of the role of the gut microbiota in GI health and, as a result, new targets are emerging. The use of a targeted approach can help to provide further insights into such studies by establishing whether increases in specific taxa are the cause, or a consequence, of such diseases. More specifically, in instances where the link between the putative pathogen and disease is not clear, the targeted removal of the microbe by bacteriocin-based approaches can establish aetiology. Even more significantly, if the target microbe is established to be a pathogen, the bacteriocin can also be employed to prevent/treat disease. Although, yet again, the harnessing of bacteriocin-producing strains to this end has remained a focus of academic research only, here we provide some examples of ways in which these bacteria could be applied.

\section{Metabolic health}

Obesity is a complex syndrome and has a number of serious implications for human health, including cardiovascular disease, type 2 diabetes (T2D), and musculoskeletal disorders. The role of the gut microbiota in obesity and overall metabolic health has received considerable attention in recent years. Initially, it was noted that the gut microbiota of genetically obese mice have been associated with an increase in the phylum Firmicutes and a decrease in the phylum Bacteroidetes ${ }^{49,50}$. However, there is conflicting evidence in human studies with regard to what the key populations involved $\operatorname{are}^{51}$. Nonetheless, the ability of the previously mentioned L. salivarius UCC118 strain to inhibit a number of Firmicutes was part of the logic behind investigating its ability to control weight gain in DIO mice ${ }^{28}$. More recent research has specifically highlighted populations that may play a role in obesity or in $\mathrm{T}^{2} \mathrm{D}^{52-57}$ that could be directly or indirectly targeted by antimicrobial action to improve intestinal balance and in turn GI health.

There have been other studies that have more specifically established the role of a particular species or strain in obesity and T2D. Fei and Zhao demonstrated the role of the endotoxin-producing Enterobacter cloacae B29 in inducing obesity and insulin resistance in germfree mice ${ }^{58}$. It was also shown that Clostridium ramosum, a species previously shown to be enriched in patients with $\mathrm{T} 2 \mathrm{D}^{56}$, promoted obesity in a gnotobiotic mouse model fed a high-fat $\operatorname{diet}^{59}$. Bacteriocins produced within the gut with specific activity against some of these organisms may be effective in beneficially balancing metabolic health. 


\section{Cancer}

There have been some suggestions that bacteriocins can be employed as anticancer agents, either through their impact on cancerous cells or through the inhibition of bacteria associated with the initiation of disease ${ }^{60}$. One such study focused on the impact of nisin on head and neck squamous cell carcinoma (HNSCC) cell apoptosis and cell proliferation in vitro and in vivo in murine oral cancer ${ }^{61}$. It was revealed that treatment with increasing concentrations of nisin induced increasing DNA fragmentation and apoptosis on three different cancer cell lines. In the oral cancer mouse model, groups receiving nisin showed reduced tumour volumes through activation of $\mathrm{CHAC1}$ expression when compared with controls, while pre-treating with nisin prior to and three weeks after tumour cell inoculation led to the same effect ${ }^{61}$. It was suggested that in this study the selective action of nisin arose from structural differences in the composition of the plasma membranes between HNSCC cells and primary keratinocytes. Although it was the nisin peptide rather than the bacteriocinproducing strain that was used, it would be interesting if strains capable of producing nisin or its variants could be used in a similar manner.

In the context of inhibiting potentially cancer-causing microbes, we refer to the example of Fusobacterium nucleatum ${ }^{62}$. Though initially regarded as a component of the oral cavity, $F$. nucleatum is also present in the gut and has been linked to playing a part in different GI disorders such as colorectal cancer (CRC), inflammatory bowel disease, and appendicitis ${ }^{63-66}$. The mechanism by which $F$. nucleatum is thought to promote CRC has been investigated ${ }^{67,68}$. As members of the genus Fusobacterium, and in particular $F$. nucleatum, play a role in numerous disease states as mentioned above, they represent an ideal target for bacteriocin-producing probiotics, but, yet again, this potential has yet to be harnessed.

\section{Future perspectives}

This review highlights the potential for bacteriocins and bacteriocin-producing probiotics as novel therapeutic treatments in many disease states, including the targeting of newly emerging pathobionts involved in a variety of gut disorders. While there is an abundance of knowledge on the application of bacteriocinproducing strains with probiotic potential in an in vitro setting, less is known of their impact in an in vivo environment and even less again with regard to their application in human health. This is undoubtedly the primary hurdle that needs to be overcome in order for the potential of the multitude of bacteriocin-producing strains that continue to be identified using traditional methods ${ }^{69-71}$ or bioinformatic approaches ${ }^{14,15}$ to be realised.

In addition to identifying new targets, recent studies have identified Akkermansia muciniphila ${ }^{72}$ and Faecalibacterium prausnitzii ${ }^{73}$ that correlate positively with gut health, as well as a decline in butyrate-producing Roseburia species in certain disease states ${ }^{56,57}$, which may play a role in future probiotic applications alongside the more traditional strains currently employed. The capacity to produce a bacteriocin by such microbes was demonstrated by Hatziioanou et al., who highlighted the first example of a bacteriocin-like substance produced by Roseburia faecis M72/1 ${ }^{74}$. Additionally, in silico screens may prove useful in identifying putative bacteriocin gene clusters from these genera/species, such as the sactipeptide-like cluster from Roseburia intestinalis L1-82 ${ }^{15}$. It will be necessary to determine whether these potential probiotics of the future have the ability to produce bacteriocins that can contribute to human health and whether this potential can be more effectively harnessed than has been the case to date. Until such time as this occurs, bacteriocin production will continue to be regarded as a probiotic trait in theory rather than in commercial reality.

\section{Competing interests}

The authors declare that they have no competing interests.

\section{Grant information}

This work was funded by a Science Foundation Ireland award "Obesibiotics" (11/P1/1137) to PDC.

The funders had no role in study design, data collection and analysis, decision to publish, or preparation of the manuscript.
1. Cotter PD, Hill C, Ross RP. Bacteriocins: developing innate immunity for food. Nat Rev Microbiol. 2005; 3(10): 777-88 PubMed Abstract | Publisher Full Text

2. Gillor $O$, Etzion A, Riley MA: The dual role of bacteriocins as anti- and probiotics. Appl Microbiol Biotechnol. 2008; 81(4): 591-606. PubMed Abstract | Publisher Full Text | Free Full Text

3. Guinane CM, Piper C, Draper LA, et al.: Impact of Environmental Factors on Bacteriocin Promoter Activity in Gut-Derived Lactobacillus salivarius. Appl Environ Microbiol. 2015; 81(22): 7851-9. PubMed Abstract | Publisher Full Text | Free Full Text

4. F Fernandez B, Le Lay C, Jean J, et al: Growth, acid production and bacteriocin production by probiotic candidates under simulated colonic conditions. J Appl Microbiol. 2013; 114(3): 877-85. PubMed Abstract | Publisher Full Text | F1000 Recommendation

5. $\quad F$ Turgis M, Vu KD, Millette M, et al:: Influence of Environmental Factors on Bacteriocin Production by Human Isolates of Lactococcus lactis MM19 and Pediococcus acidilactici MM33. Probiotics Antimicrob Proteins. 2016; 8(1): 53-9. PubMed Abstract | Publisher Full Text | F1000 Recommendation
6. Cotter PD, Ross RP Hill C. Bacteriocins - a viable alternative to antibiotics? Nat Rev Microbiol. 2013; 11(2): 95-105. PubMed Abstract | Publisher Full Text

7. Dobson A, Cotter PD, Ross RP, et al:: Bacteriocin production: a probiotic trait? Appl Environ Microbiol. 2012; 78(1): 1-6. PubMed Abstract | Publisher Full Text | Free Full Text

8. Walsh MC, Gardiner GE, Hart OM, et al.: Predominance of a bacteriocinproducing Lactobacillus salivarius component of a five-strain probiotic in the porcine ileum and effects on host immune phenotype. FEMS Microbiol Ecol. 2008; 64(2): 317-27.

PubMed Abstract | Publisher Full Text

9. Corr SC, Li Y, Riedel CU, et al:: Bacteriocin production as a mechanism for the antiinfective activity of Lactobacillus salivarius UCC118. Proc Natl Acad Sci U S A. 2007; 104(18): 7617-21.

PubMed Abstract | Publisher Full Text | Free Full Text

10. van Hemert S, Meijerink M, Molenaar D, et al.: Identification of Lactobacillus plantarum genes modulating the cytokine response of human peripheral blood mononuclear cells. BMC Microbiol. 2010; 10: 293 PubMed Abstract | Publisher Full Text | Free Full Text 
11. Drider D, Bendali F, Naghmouchi K, et al.: Bacteriocins: Not Only Antibacterial Agents. Probiotics Antimicrob Proteins. 2016; 1-6. PubMed Abstract | Publisher Full Text

12. Hill C, Guarner F, Reid G, et al.: Expert consensus document. The International Scientific Association for Probiotics and Prebiotics consensus statement on the scope and appropriate use of the term probiotic. Nat Rev Gastroenterol Hepatol. 2014; 11(8): 506-14.

PubMed Abstract | Publisher Full Text

13. Martinez FA, Balciunas EM, Converti A, et al.: Bacteriocin production by Bifidobacterium spp. A review. Biotechnol Adv. 2013; 31(4): 482-8. PubMed Abstract | Publisher Full Text

14. F Zheng J, Gänzle MG, Lin XB, et al:: Diversity and dynamics of bacteriocins from human microbiome. Environ Microbiol. 2015; 17(6): 2133-43. PubMed Abstract | Publisher Full Text | F1000 Recommendation

15. Walsh CJ, Guinane CM, Hill C, et al:: In silico identification of bacteriocin gene clusters in the gastrointestinal tract, based on the Human Microbiome Project's reference genome database. BMC Microbiol. 2015; 15: 183. PubMed Abstract | Publisher Full Text | Free Full Text

16. Guarner F, Khan AG, Garisch J, et al:: World Gastroenterology Organisation Global Guidelines: probiotics and prebiotics October 2011. J Clin Gastroenterol. 2012; 46(6): 468-81.

PubMed Abstract | Publisher Full Text

17. Sanders ME, Guarner F, Guerrant R, et al:: An update on the use and investigation of probiotics in health and disease. Gut. 2013; 62(5): 787-796. PubMed Abstract | Publisher Full Text | Free Full Text

18. Meijerink M, van Hemert S, Taverne N, et al.: Identification of genetic loci in Lactobacillus plantarum that modulate the immune response of dendritic cells using comparative genome hybridization. PLoS One. 2010; 5(5): e10632. PubMed Abstract | Publisher Full Text | Free Full Text

19. Gotteland M, Andrews M, Toledo M, et al:: Modulation of Helicobacter pylori colonization with cranberry juice and Lactobacillus johnsonii La1 in children. Nutrition. 2008; 24(5): 421-6.

PubMed Abstract | Publisher Full Tex

20. Stern NJ, Svetoch EA, Eruslanov BV, et al.: Isolation of a Lactobacillus salivarius strain and purification of its bacteriocin, which is inhibitory to Campylobacter jejuni in the chicken gastrointestinal system. Antimicrob Agents Chemother. 2006; 50(9): 3111-6.

PubMed Abstract | Publisher Full Text | Free Full Text

21. Svetoch EA, Eruslanov BV, Levchuk VP, et al:: Isolation of Lactobacillus salivarius 1077 (NRRL B-50053) and characterization of its bacteriocin, including the antimicrobial activity spectrum. Appl Environ Microbiol. 2011; 77(8): 2749-54. PubMed Abstract | Publisher Full Text | Free Full Text

22. O'Shea EF, Gardiner GE, O'Connor PM, et al.: Characterization of enterocin- and salivaricin-producing lactic acid bacteria from the mammalian gastrointestina tract. FEMS Microbiol Lett. 2009; 291(1): 24-34.

PubMed Abstract | Publisher Full Text

23. O'Shea EF, O'Connor PM, Raftis EJ, et al.: Production of multiple bacteriocins from a single locus by gastrointestinal strains of Lactobacillus salivarius. J Bacteriol. 2011; 193(24): 6973-82.

PubMed Abstract | Publisher Full Text | Free Full Text

24. O'Shea EF, O'Connor PM, O'Sullivan O, et al.: Bactofencin A, a new type of cationic bacteriocin with unusual immunity. MBio. 2013; 4(6): e00498-13. PubMed Abstract | Publisher Full Text | Free Full Text

25. Guinane CM, Lawton EM, O'Connor PM, et al.: The bacteriocin bactofencin A subtly modulates gut microbial populations. Anaerobe. 2016; 40: 41-9. PubMed Abstract | Publisher Full Text

26. Flynn S, van Sinderen D, Thornton GM, et al:: Characterization of the genetic locus responsible for the production of ABP-118, a novel bacteriocin produced by the probiotic bacterium Lactobacillus salivarius subsp. salivarius UCC118. Microbiology. 2002; 148(Pt 4): 973-84.

PubMed Abstract | Publisher Full Tex

27. Dunne C, Murphy L, Flynn S, et al:: Probiotics: from myth to reality. Demonstration of functionality in animal models of disease and in human clinical trials. Antonie Van Leeuwenhoek. 1999; 76(1-4): 279-92. PubMed Abstract | Publisher Full Text

28. Murphy EF, Cotter PD, Hogan A, et al:: Divergent metabolic outcomes arising from targeted manipulation of the gut microbiota in diet-induced obesity. Gut. 2013; 62(2): 220-6.

PubMed Abstract | Publisher Full Text

29. van Pijkeren JP, Canchaya C, Ryan KA, et al: Comparative and functional analysis of sortase-dependent proteins in the predicted secretome of Lactobacillus salivarius UCC118. Appl Environ Microbiol. 2006; 72(6): 4143-53. PubMed Abstract | Publisher Full Text | Free Full Text

30. O'Callaghan J, Buttó LF, MacSharry J, et al:: Influence of adhesion and bacteriocin production by Lactobacillus salivarius on the intestinal epithelial cell transcriptional response. Appl Environ Microbiol. 2012; 78(15): 5196-203. PubMed Abstract | Publisher Full Text | Free Full Text

31. Shah NP: Functional cultures and health benefits. Int Dairy J. 2007; 17(11): 1262-1277.

Publisher Full Text

32. Bull M, Plummer S, Marchesi J, et al:: The life history of Lactobacillus acidophilus as a probiotic: a tale of revisionary taxonomy, misidentification and commercial success. FEMS Microbiol Lett. 2013; 349(2): 77-87. PubMed Abstract | Publisher Full Text

33. Sanders ME, Klaenhammer TR: Invited review: the scientific basis of Lactobacillus acidophilus NCFM functionality as a probiotic. J Dairy Sci. 2001; 84(2): 319-31.

PubMed Abstract | Publisher Full Text

34. Tabasco R, García-Cayuela T, Peláez C, et al:: Lactobacillus acidophilus La- 5 increases lactacin $B$ production when it senses live target bacteria. Int J Food Microbiol. 2009; 132(2-3): 109-16.

PubMed Abstract | Publisher Full Text

35. Barefoot SF, Klaenhammer TR: Purification and characterization of the Lactobacillus acidophilus bacteriocin lactacin B. Antimicrob Agents Chemother 1984; 26(3): 328-34.

PubMed Abstract | Publisher Full Text | Free Full Text

36. Aas JA, Paster BJ, Stokes LN, et al:: Defining the normal bacterial flora of the oral cavity. J Clin Microbiol. 2005; 43(11): 5721-32. PubMed Abstract | Publisher Full Text | Free Full Text

37. Pearce C, Bowden GH, Evans M, et al.: Identification of pioneer viridans streptococci in the oral cavity of human neonates. J Med Microbiol. 1995; 42(1): 67-72.

PubMed Abstract | Publisher Full Text

38. Burton JP, Chilcott CN, Tagg JR: The rationale and potential for the reduction of oral malodour using Streptococcus salivarius probiotics. Oral Dis. 2005; 11(Suppl 1): 29-31.

PubMed Abstract | Publisher Full Text

39. Burton JP, Wescombe PA, Moore CJ, et al:: Safety assessment of the oral cavity probiotic Streptococcus salivarius K12. Appl Environ Microbiol. 2006; 72(4): 3050-3. PubMed Abstract | Publisher Full Text | Free Full Text

40. Wescombe PA, Hale JD, Heng NC, et al:: Developing oral probiotics from Streptococcus salivarius. Future Microbiol. 2012; 7(12): 1355-71. PubMed Abstract | Publisher Full Text

41. Patras KA, Wescombe PA, Rösler B, et al.: Streptococcus salivarius K12 Limits Group B Streptococcus Vaginal Colonization. Infect Immun. 2015; 83(9): 3438-44. PubMed Abstract | Publisher Full Text | Free Full Text

42. Heng NC, Haji-Ishak NS, Kalyan A, et al:: Genome sequence of the bacteriocinproducing oral probiotic Streptococcus salivarius strain M18. J Bacteriol. 2011; 193(22): 6402-3.

PubMed Abstract | Publisher Full Text | Free Full Text

43. F Burton JP, Drummond BK, Chilcott CN, et al:: Influence of the probiotic Streptococcus salivarius strain M18 on indices of dental health in children: a randomized double-blind, placebo-controlled trial. J Med Microbiol. 2013; 62(Pt 6): $875-84$.

PubMed Abstract | Publisher Full Text | F1000 Recommendation

44. F Burton JP, Wescombe PA, Macklaim JM, et al:: Persistence of the oral probiotic Streptococcus salivarius M18 is dose dependent and megaplasmid transfer can augment their bacteriocin production and adhesion characteristics. PLoS One. 2013; 8(6): e65991.

PubMed Abstract | Publisher Full Text | Free Full Text | F1000 Recommendation

45. Wescombe PA, Upton M, Renault P, et al:: Salivaricin 9, a new lantibiotic produced by Streptococcus salivarius. Microbiology. 2011; 157(Pt 5): 1290-9. PubMed Abstract | Publisher Full Text

46. F Walker GV, Heng NC, Carne A, et al.: Salivaricin E and abundant dextranase activity may contribute to the anti-cariogenic potential of the probiotic candidate Streptococcus salivarius JH. Microbiology. 2016; 162(3): 476-86. PubMed Abstract | Publisher Full Text | F1000 Recommendation

47. F Kommineni S, Bretl DJ, Lam V, et al:: Bacteriocin production augments niche competition by enterococci in the mammalian gastrointestinal tract. Nature. 2015; 526(7575): 719-22.

PubMed Abstract | Publisher Full Text | Free Full Text | F1000 Recommendation

48. F Janek D, Zipperer A, Kulik A, et al:: High Frequency and Diversity of Antimicrobial Activities Produced by Nasal Staphylococcus Strains against Bacterial Competitors. PLoS Pathog. 2016; 12(8): e1005812. PubMed Abstract | Publisher Full Text | Free Full Text | F1000 Recommendation

49. $\mathrm{F}$ Ley $\mathrm{RE}$, Bäckhed $\mathrm{F}$, Turnbaugh $\mathrm{P}$, et al:: Obesity alters gut microbial ecology. Proc Natl Acad Sci U S A. 2005; 102(31): 11070-5. PubMed Abstract | Publisher Full Text | Free Full Text | F1000 Recommendation

50. F Turnbaugh PJ, Ley RE, Mahowald MA, et al:: An obesity-associated gut microbiome with increased capacity for energy harvest. Nature. 2006 444(7122): 1027-31.

PubMed Abstract | Publisher Full Text | F1000 Recommendation

51. Schwiertz A, Taras D, Schäfer K, et al:: Microbiota and SCFA in lean and overweight healthy subjects. Obesity (Silver Spring). 2010; 18(1): 190-5. PubMed Abstract | Publisher Full Text

52. F Turnbaugh PJ, Bäckhed F, Fulton L, et al:: Diet-induced obesity is linked to marked but reversible alterations in the mouse distal gut microbiome. Cell Host Microbe. 2008; 3(4): 213-23.

PubMed Abstract | Publisher Full Text | Free Full Text | F1000 Recommendation

53. F Le Chatelier E, Nielsen T, Qin J, et al.: Richness of human gut microbiome correlates with metabolic markers. Nature. 2013; 500(7464): 541-6. PubMed Abstract | Publisher Full Text | F1000 Recommendation 
54. F Everard A, Belzer C, Geurts L, et al:: Cross-talk between Akkermansia muciniphila and intestinal epithelium controls diet-induced obesity. Proc Nat Acad Sci U S A. 2013; 110(22): 9066-71.

PubMed Abstract | Publisher Full Text | Free Full Text | F1000 Recommendation

55. Larsen N, Vogensen FK, van den Berg FW, et al.: Gut microbiota in human adults with type 2 diabetes differs from non-diabetic adults. PLoS One. 2010; 5(2): e9085.

PubMed Abstract | Publisher Full Text | Free Full Text

56. F Qin J, LiY Cai Z, et al: A metagenome-wide association study of gut microbiota in type 2 diabetes. Nature. 2012; 490(7418): 55-60. PubMed Abstract | Publisher Full Text | F1000 Recommendation

57. Karlsson FH, Tremaroli V, Nookaew I, et al.: Gut metagenome in European women with normal, impaired and diabetic glucose control. Nature. 2013; 498(7452): 99-103. PubMed Abstract | Publisher Full Text

58. F Fei N, Zhao L: An opportunistic pathogen isolated from the gut of an obese human causes obesity in germfree mice. ISME J. 2013; 7(4): 880-4. PubMed Abstract | Publisher Full Text | Free Full Text | F1000 Recommendation

59. F Woting A, Pfeiffer N, Loh G, et al:: Clostridium ramosum promotes high-fat diet-induced obesity in gnotobiotic mouse models. MBio. 2014; 5(5): e01530-14. PubMed Abstract | Publisher Full Text | Free Full Text | F1000 Recommendation

60. Kaur S, Kaur S: Bacteriocins as Potential Anticancer Agents. Front Pharmacol. 2015; 6: 272 . PubMed Abstract | Publisher Full Text | Free Full Text

61. F Joo NE, Ritchie K, Kamarajan P, et al.: Nisin, an apoptogenic bacteriocin and food preservative, attenuates HNSCC tumorigenesis via CHAC1. Cance Med. 2012; 1(3): 295-305 PubMed Abstract | Publisher Full Text | Free Full Text | F1000 Recommendation

62. Allen-Vercoe E, Strauss J, Chadee K: Fusobacterium nucleatum: an emerging gut pathogen? Gut Microbes. 2011; 2(5): 294-8. PubMed Abstract | Publisher Full Text

63. Castellarin $\mathrm{M}$, Warren $\mathrm{RL}$, Freeman JD, et al: Fusobacterium nucleatum infection is prevalent in human colorectal carcinoma. Genome Res. 2012; 22(2): 299-306. PubMed Abstract | Publisher Full Text | Free Full Text

64. Kostic AD, Chun E, Robertson L, et al.: Fusobacterium nucleatum potentiates intestinal tumorigenesis and modulates the tumor-immune microenvironment. Cell Host Microbe. 2013; 14(2): 207-15. PubMed Abstract | Publisher Full Text | Free Full Text

65. Strauss J, Kaplan GG, Beck PL, et al.: Invasive potential of gut mucosa-derived
Fusobacterium nucleatum positively correlates with IBD status of the host Inflamm Bowel Dis. 2011; 17(9): 1971-8.

PubMed Abstract | Publisher Full Text

66. F Swidsinski A, Dörffel Y, Loening-Baucke V, et al:: Acute appendicitis is characterised by local invasion with Fusobacterium nucleatum/necrophorum. Gut. 2011; 60(1): 34-40.

PubMed Abstract | Publisher Full Text | F1000 Recommendation

67. Rubinstein MR, Wang X, Liu W, et al:: Fusobacterium nucleatum promotes colorectal carcinogenesis by modulating E-cadherin/ $\beta$-catenin signaling via its FadA adhesin. Cell Host Microbe. 2013; 14(2): 195-206. PubMed Abstract | Publisher Full Text | Free Full Text

68. Gur C, Ibrahim Y, Isaacson B, et al:: Binding of the Fap2 protein of Fusobacterium nucleatum to human inhibitory receptor TIGIT protects tumors from immune cell attack. Immunity. 2015; 42(2): 344-55. PubMed Abstract | Publisher Full Text | Free Full Text

69. O'Shea EF, Gardiner GE, O'Connor PM, et al:: Characterization of enterocin- and salivaricin-producing lactic acid bacteria from the mammalian gastrointestinal tract. FEMS Microbiol Lett. 2009; 291(1): 24-34.

PubMed Abstract | Publisher Full Text

70. F Rea MC, Sit CS, Clayton E, et al.: Thuricin CD, a posttranslationally modified bacteriocin with a narrow spectrum of activity against Clostridium difficile. Proc Natl Acad Sci U S A. 2010; 107(20): 9352-7.

PubMed Abstract | Publisher Full Text | Free Full Text | F1000 Recommendation

71. Birri DJ, Brede DA, Nes IF, et al:: Salivaricin D, a novel intrinsically trypsinresistant lantibiotic from Streptococcus salivarius 5M6c isolated from a healthy infant. Appl Environ Microbiol. 2012; 78(2): 402-10.

PubMed Abstract | Publisher Full Text | Free Full Text

72. Dao MC, Everard A, Aron-Wisnewsky J, et al.: Akkermansia muciniphila and improved metabolic health during a dietary intervention in obesity: relationship with gut microbiome richness and ecology. Gut. 2016; 65(3): 426-36.

PubMed Abstract | Publisher Full Text

73. $\mathrm{F}$ Miquel S, Leclerc M, Martin R, et al.: Identification of metabolic signatures linked to anti-inflammatory effects of Faecalibacterium prausnitzii. MBio. 2015: 6(2): pii: e00300-15

PubMed Abstract | Publisher Full Text | Free Full Text | F1000 Recommendation

74. F Hatziioanou D, Mayer MJ, Duncan SH, et al:: A representative of the dominant human colonic Firmicutes, Roseburia faecis M72/1, forms a nove bacteriocin-like substance. Anaerobe. 2013; 23(7): 5-8.

PubMed Abstract | Publisher Full Text | F1000 Recommendation 


\section{Open Peer Review}

\section{Current Peer Review Status:}

\section{Editorial Note on the Review Process}

Faculty Reviews are review articles written by the prestigious Members of Faculty Opinions. The articles are commissioned and peer reviewed before publication to ensure that the final, published version is comprehensive and accessible. The reviewers who approved the final version are listed with their names and affiliations.

\section{The reviewers who approved this article are:}

\section{Version 1}

\section{Antonio Galvez}

Área de Microbiología, Departamento de Ciencias de la Salud, Facultad de Ciencias Experimentales, Universidad de Jaén, Jaén, Spain

Competing Interests: No competing interests were disclosed.

\section{Michael Chikindas}

1 School of Environmental and Biological Sciences, Rutgers State University, New Brunswick, NJ, USA

2 Center for Digestive Health, New Jersey Institute for Food, Nutrition and Health, New Brunswick, NJ, USA

Competing Interests: No competing interests were disclosed.

The benefits of publishing with F1000Research:

- Your article is published within days, with no editorial bias

- You can publish traditional articles, null/negative results, case reports, data notes and more

- The peer review process is transparent and collaborative

- Your article is indexed in PubMed after passing peer review

- Dedicated customer support at every stage

For pre-submission enquiries, contact research@f1000.com 